\title{
Manajemen Pondok Pesantren di Indonesia dalam Perspektif Pendidikan Islam Era Modern
}

\author{
Firman Mansir \\ Universitas Muhammadiyah Yogyakarta \\ firmanmansir@umy.ac.id
}

Naskah diterima: 18 Oktober 2020 | Disetujui: 18 Desember 2020 | Diterbitkan: 23 Desember 2020

\begin{abstract}
This research describes the management of the development of Islamic boarding schools in the modern era. It begins with identifying and analyzing the historical dynamics of the development of Islamic boarding schools in order to be able to develop an appropriate education system to be applied to modern Islamic boarding schools. It should be done to find out the right strategy to be applied to Islamic boarding schools in order to increase its existence as an Islamic educational institution in current conditions that have changed in a modern way. In this research, the method used is a qualitative method by conducting a study based on document analysis. The author collects, identifies, analyzes, and synthesizes the data obtained, then makes interpretations of policies, concepts, and events. The analysis used is policy analysis, which is a form of analyzing various documents related to a policy in the management of Islamic boarding schools.
\end{abstract}

Keywords: boarding school; islamic education; management; modern

\begin{abstract}
Abstrak
Penelitian ini menggambarkan tentang manajemen pengembangan pondok pesantren di era modern. Diawali dengan mengidentifikasi dan menganalisis dinamika sejarah perkembangan pondok pesantren untuk dapat mengembangkan sistem pendidikan yang tepat untuk diterapkan pada pondok pesantren yang modern. Hal ini dilakukan untuk dapat mengetahui strategi yang tepat untuk diterapkan pada pondok pesantren supaya dapat meningkatkan eksistensinya sebagai lembaga pendidikan Islam di kondisi lingkungan yang telah berubah secara modern. Pada penelitian ini metode yang digunakan adalah metode kualitatif dengan melakukan pengkajian yang berdasar analisis dokumen. Penulis mengumpulkan, melakukan identifikasi, melakukan analisis, serta mengadakan sintesis terhadap data yang didapat, kemudian melakukan interpretasi terhadap kebijakan, konsep, serta peristiwa. Analisis yang dipakai yaitu analisis kebijakan yang merupakan bentuk menganalisis berbagai dokumen yang berkaitan dengan suatu kebijakan di bidang manajemen pondok pesantren.
\end{abstract}

Kata Kunci: manajemen; modern; pendidikan Islam; pondok pesantren open access article under the CC BY-SA 4.0 license. DOI: 10.37680/qalamuna.v12i2.644 


\section{Pendahuluan}

Pendidikan merupakan tombak utama bagi kemajuan bangsa. Pendidikan lebih dari sekedar pengajaran yang dikatakan sebagai proses transfer ilmu belaka, dan bukan transformasi nilai dan pembentukan kepribadian (Azra, 2019). Dalam memperbaiki sistem pendidikan tidak hanya memperbaiki guru pengajar serta fasilitas dalam pendidikan, tetapi juga harus adanya perbaikan manajemen dalam dunia pendidikan tersebut. Dalam pendidikan Islam sangat mungkin terjadi adanya kebimbangan untuk melestarikan tradisi salaf dan juga untuk memodernisasikan sesuai dengan tuntutan perubahan zaman. Lembaga pendidikan Islam dipacu untuk merancang metode serta model pendidikan yang dirasa sesuai dengan pendidikan di era modern. Para kiai di Indonesia telah banyak melakukan upaya untuk mengatasi ketertinggalan pendidikan yang ada di dunia pesantren.

Dalam tinjauan historis, dapat diketahui bahwa pesantren berasal dari kata santri yang diimbuhi awalan 'pe-' serta diimbuhi akhiran '-an'. Kata 'santri' adalah sebuah gabungan dari dua suku kata 'sant' yang berarti manusia baik dan 'tra' yang berarti suka menolong, sehingga pondok pesantren memiliki arti sebuah tempat yang digunakan untuk pendidikan guna membimbing manusia menjadi orang baik (Hayati, 2015), atau center of significance (Muzakki \& Nisa', 2020). Pada masa-masa awal pembentukannya, pesantren tumbuh dan berkembang dengan menyandang ciri-ciri tradisionalitasnya. Akan tetapi pada masa-masa berikutnya, pesantren sebagai lembaga pendidikan Islam telah mengalami perkembangan bentuk sesuai dengan perubahan zaman, terutama sekali adanya dampak kemajuan ilmu pengetahuan dan teknologi dari masa ke masa, sebagaimana dikaji Rohmatulloh (2018).

Di Indonesia sendiri terdapat tiga jenis pondok pesantren yaitu: pertama, pondok pesantren tradisional. Pondok pesantren tradisional atau salafiyah ini merupakan pondok pesantren yang terlaksana pada saat awal berdirinya pondok pesantren. Pondok pesantren salafiyah ini mengajarkan kitab-kitab yang telah ditulis ulama pada abad ke 15 dengan berbahasa Arab (Mahfud \& Hairit, 2016). Kedua, pondok pesantren modern atau pondok pesantren khalafiyah, pondok ini merupakan pesantren yang sudah lebih dikembangkan mengikuti perubahan zaman, dalam pembelajarannya juga dengan sistem belajar klasik. Dan ketiga, pondok pesantren campuran yaitu pondok pesantren yang menggunakan sistem pembelajaran campuran antara tradisional dan modern (Halim \& Mas'ud, 2005).

Pondok pesantren modern merupakan perubahan dari pondok pesantren tradisional. Dalam mengubah sistem pondok pesantren dapat dilakukan dengan berdasarkan tiga pembaharuan dalam pendidikan Islam yaitu, yang pertama adalah dengan dapatnya menerima sistem pendidikan sekuler modern yang digunakan di Barat, tetapi dengan tetap memasukkan ajaran-ajaran agama Islam. Kedua, lebih menyederhanakan silabus yang terbentuk secara tradisional. Ketiga, menggabungkan cabang-cabang ilmu pengetahuan baru. Di Indonesia sendiri dunia pendidikan Islam memiliki kelemahan yaitu dalam penguasaan bahasa asing, metode penelitian ilmu agama Islam atau metode pemahaman Islam, serta minat ilmu (Hasan, 2016).

Jadi, dapat disimpulkan bahwa pondok pesantren itu sendiri adalah lembaga keagamaan yang memiliki tugas mengajarkan pendidikan dan menyebarluaskan ajaran agama Islam. Maka, manajemen pengembangan pondok pesantren berarti sebuah proses pencapaian tujuan tertentu 
dengan pengorganisasian melalui kerjasama dengan orang lain dalam pengembangan pondok pesantren atau tempat pendidikan untuk membimbing seseorang menjadi lebih baik.

Dampak globalisasi sebagai akibat dari kemajuan di bidang informasi terhadap peradaban dunia dan merujuk kepada suatu pengaruh yang luas sekali (Nata, 2012). Pada era sekarang ini banyak pondok pesantren yang sudah berubah dari lembaga pendidikan agama non-formal menjadi lembaga pendidikan formal dengan mendirikan sekolah dan madrasah formal mengikuti aturan pemerintah meski tidak melupakan pola tradisional dari pondok pesantren itu sendiri. Pengurus pondok pesantren harus memiliki pengelolaan yang baik yaitu pengelolaan internal serta eksternal. Salah satu pengelolaan internal adalah pengelolaan bagian keuangan. Pengelolaan keuangan pondok pesantren dapat lebih baik dengan ditulisnya bukti keuangan, yaitu pemasukan dan pengeluaran dana pondok pesantren dengan didukung bukti-buktinya. Hal ini agar sistem keuangan pondok pesantren menjadi transparan dan wali santri lebih mengetahui umpan balik yang didapatkan oleh santri agar tidak ada kecurigaan dari wali santri terhadap pondok pesantren.

Modernisasi sistem pendidikan pondok pesantren di era modern saat ini dilatarbelakangi oleh adanya sistem atau pendidikan di masa lalu yang dirasa sudah tidak efektif diterapkan di era modern saat ini. Pondok pesantren di Indonesia yang masih menggunakan sistem lama diharapkan untuk beradaptasi dengan sistem pendidikan di era modern dengan mulai mengembangkan manajemen pendidikan di masing-masing pondok pesantren, tanpa harus meninggalkan budaya pesantren yang sudah ada. Kegiatan-kegiatan yang dapat dilakukan dalam mengembangkan pondok pesantren yang modern secara substansial harus ada beberapa aspek yang harus diperhatikan yaitu sebagai berikut:

1. Aspek masyarakat; memberikan program-program yang dapat dikembangkan oleh pondok pesantren untuk mengembangkan keterampilan yang dimiliki masyarakat.

2. Aspek budaya; muncul sebagai nilai dan norma yang dapat mengontrol pengembangan manajemen pondok pesantren agar selalu dapat diterima.

Berangkat dari latar belakang tersebut, penulis tertarik untuk mengkaji bagaimana manajemen pondok pesantren dapat dikembangkan melalui sudut pandang atau perspektif pendidikan Islam di era modern. Pada penelitian ini, metode yang digunakan adalah metode kualitatif dengan pendekatan studi literatur yang disertai dengan kajian analitis dokumen. Penulis mengumpulkan, melakukan identifikasi, melakukan analisis, serta mengadakan sintesis terhadap data yang kemudian melakukan interpretasi terhadap kebijakan, konsep, serta peristiwa. Analisis yang dipakai yaitu analisis kebijakan yang merupakan bentuk menganalisis berbagai dokumen yang berkaitan dengan suatu kebijakan. Selain itu, penulis juga memakai analisis historis, yang merupakan penganalisisan data kegiatan, program, serta kebijakan yang telah dilakukan pada masa lalu. Kajian ini melakukan analisis terhadap kebijakan dan manajemen pendidikan Islam khususnya yang di dalamnya ada pondok pesantren. Penelitian ini juga melakukan penggalian, penemuan, pembacaan, penjelasan, serta penyampaian pada suatu pustaka secara tersirat maupun tersurat dari data-data yang telah dikumpulkan dari pustaka tersebut, sebuah cara yang digunakan dengan menelaah buku atau materimateri yang berhubungan dengan topik yang akan diulas (Yahya, 2016). Adapun teknik yang digunakan untuk menganalisis topik manajemen pengembangan pondok pesantren ini adalah dengan mengumpulkan beberapa data terkait dan juga strategi atau cara yang dapat dilakukan untuk pengembangan pondok pesantren di era modern. Data yang digunakan dalam penelitian ini berasal dari jurnal dan buku terkait manajemen dan pengembangan pondok pesantren. 


\section{Manajemen Pendidikan Islam}

\section{Pengelolaan Manajemen Pendidikan Islam di Era Modern}

Secara etimologis, kata manajemen berasal dari bahasa Inggris yaitu management yang artinya pimpinan atau pengurus, kemudian diartikan ke dalam bahasa Indonesia artinya pengelolaan. Manajemen sendiri merupakan ilmu dan seni mengatur proses pemanfaatan SDM serta sumbersumber lainnya secara efektif guna mencapai tujuan tertentu. Menurut Soekarno, manajemen merupakan suatu proses atau kegiatan atau usaha untuk pencapaian tujuan tertentu dengan bekerjasama dengan orang-orang lain (Suryana, 2017). Diskusi mengenai manajemen pendidikan khususnya pada manajemen pendidikan Islam adalah hal yang selalu menjadi daya tarik. Hal ini tidak terlepas dari maraknya lembaga pendidikan Islam yang saat ini terdapat pondok pesantren di dalamnya.

Pada dasarnya manajemen pendidikan merupakan gabungan dua kata yang berbeda tetapi membentuk satu makna, yaitu manajemen dan pendidikan dalam arti yang sesungguhnya merupakan pengelolaan terhadap suatu kebutuhan institusional dalam pendidikan dengan cara yang efektif dan efisien. Manajemen pendidikan atau manajemen pesantren juga merupakan aktivitas untuk mencapai tujuan, atau proses penyelenggaraan kerja agar dapat mencapai suatu tujuan pendidikan Islam yang telah ditetapkan dan juga hal itu merupakan komponen dari sebuah sistem yang semua subsistemnya saling berkaitan satu dengan yang lainnya (Romlah, 2016). Pada hakikatnya, manajemen pendidikan adalah suatu usaha yang berhubungan dengan aktivitas pendidikan yang terjadi dengan adanya proses memotivasi kreativitas dan mempengaruhi anak didik dengan alat-alat pendidikan, metode, media, sarana, dan prasarana yang diperlukan dalam pelaksanaan pendidikan.

Manajemen pendidikan merupakan hal yang perlu diprioritaskan dan menjadi perhatian untuk kelangsungan proses pendidikan sehingga dapat menghasilkan output yang berkualitas dan sesuai dengan tujuan awal. Dewasa ini, kenyataannya banyak institusi pendidikan negeri maupun swasta yang mempunyai manajemen pendidikan yang bagus dan berkualitas tinggi dengan mengikuti perkembangan zaman dan teknologi. Namun, tidak sedikit pula institusi pendidikan yang belum memenuhi kriteria sehingga bisa dikatakan kurang baik dalam mengelola atau dalam memanajemen pendidikan. Karena itu secara sosial tidak selamanya manajemen waktu yang perlu diperhatikan dalam hal berbagai prioritas, melainkan tugas apa saja yang mesti diperhatikan dan dibutuhkan. Oleh karena itu, yang perlu dilakukan dalam hal ini yaitu:

a) Membuat daftar tugas

b) Mengerjakan tugas dengan baik

c) Memakai aplikasi untuk mendahulukan tugas yang prioritas

d) Fokus pada pekerjaan sendiri

Dengan demikian, hal tersebut merupakan salah satu masalah yang perlu diperbaiki oleh pemerintah sebagai aplikasi dari kebijakan yang menginginkan terwujudnya pendidikan berkualitas yang merata di seluruh Indonesia guna mencerdaskan kehidupan bangsa. Di tengah suasana pendidikan yang terus bergerak secara dinamis, terutama diakibatkan dari adanya perkembangan zaman dan teknologi kehidupan global yang amat kompleks, maka pendidikan pesantren pun harus dikelola sesuai dengan tuntutan perubahan dan keadaan saat ini. Pengelolaan dengan cara 
konvensional dan menerapkan cara-cara lama yang serba tradisional sudah tidak efektif lagi, pondok pesantren perlu dikelola dengan cara dan inovasi baru, secara adaptif, kreatif, dan inovatif agar tidak tertinggal di era yang serba modern.

\section{Unsur-unsur dan Tujuan Manajemen Pendidikan Islam}

Pendidikan Islam dalam proses pengelolaannya agar mencapai tujuan dengan sebaik-baiknya, mengandung beberapa unsur dan poin dari manajemen pendidikan yang digunakan untuk menunjang jalannya proses pendidikan. Di antara unsur-unsur dari manajemen pendidikan, merujuk pada Muhs (1982) adalah:

1) SDM: yaitu tenaga kerja manusia yang digerakan untuk melaksanakan proses manajemen dalam mencapai tujuan.

2) Dana atau uang: Hal ini diperlukan untuk proses pelaksanaan dan pencapaian tujuan.

3) Metode: ini merupakan cara atau sistem untuk mencapai tujuan.

4) Bahan pendidikan: yaitu bahan-bahan yang diperlukan sebagai sumberdaya pendidikan yang mencapai tujuan pendidikan.

5) Mesin yang berjalan: yaitu mesin mesin yang dibutuhkan sebagai pembantu pekerjaan menjadi lebih ringan efektif, dan efisien.

6) Promosi: pasaran atau tempat menjual atau melempar hasil produksi, dalam hal ini yang dimaksud adalah peserta didik. Semua unsur di atas saling berkaitan satu sama lainnya sebagai kesatuan yang dibutuhkan guna mencapai tujuan yang diinginkan.

Sementara itu, menurut Hidayat \& Machali (2012), dalam tujuan adanya manajemen pendidikan perlu dijabarkan dan digambarkan sebagai berikut antara lain:

1) Terciptanya suasana belajar dan proses pembelajaran yang aktif, inovatif, kreatif, efektif dan selalu menyenangkan

2) Menciptakan output yang berkualitas tinggi, dalam hal ini output dari pendidikan adalah peserta didik yang mampu mengembangkan potensi, memiliki kekutan spiritual keagamaan, moral, sikap dan karakter yang baik

3) Tercapainya tujuan umum pendidikan dengan efektif dan efisien

4) Teratasinya masalah-masalah dalam pendidikan.

5) Terbekalinya tenaga pendidikan dengan berbagai pengalaman administrasi manajemen dalam pendidikan.

\section{Pondok Pesantren Modern}

\section{Model Manajemen Pondok Pesantren Modern}

Sejak zaman dahulu, adanya pondok pesantren selalu dikaitkan dengan khas pendidikan Islam Jawa. Tetapi seiring dengan perkembangan zaman yang semakin modern, pendidikan Islam Jawa mulai menyebar ke luar wilayah pulau Jawa dan menyebar ke seluruh kota besar yang terdapat di 
Indonesia. Pondok pesantren merupakan contoh lembaga pendidikan yang menerapkan sistem boarding school yaitu salah satu karakteristik dasar pendidikan pesantren yang selama ini dikenal dengan sistem santri mukim atau mondok (Sugiarti, 2011). Menurut Madjid (1997), pesantren disebut sebagai lembaga yang tidak hanya identik dengan keislamannya saja tetapi juga mengandung makna keaslian Indonesia atau indigenous yang muncul dan berkembang terkait erat dengan komunitas lingkungannya.

Hal tersebut dapat dilihat dari pengurusnya yang melibatkan dalam pemberian tanah wakaf, sadaqah, hibah dari masyarakat, dan sebagainya. Selain masyarakat sekitar peduli kepada pondok pesantren, begitu pula dengan pondok pesantren yang juga peduli terhadap komunitas yang ada di lingkungan masyarakat. Pondok pesantren memberikan ilmu agama, ilmu sosial, ilmu ekonomi, bahkan kultur budaya yang ada di masyarakat mereka berikan guna menunjang kemapanan kehidupan masyarakat sehingga saling menguntungkan antar masyarakat dan pengurus pondok pesantren. Konteks yang diterapkan oleh pondok pesantren baik pengurus dan kiai adalah konteks yang diterapkan oleh antropolog Clifford Geertz disebut sebagai "cultural brokers" dalam arti yang seluas-luasnya (Sugiarti, 2011).

Peraturan pengembangan pondok pesantren di era modern yang sesuai dengan sekarang ini, menurut Syafa'at et al. (2014) adalah:

1) Penerapan sistem pengaturan manajemen di sentral pendidikan yang sudah dikelola,

2) Penerapan sistem manajemen keuangan sentral yang bisa dikelola,

3) Adanya tambahan fasilitas kamar dan ruang pendidikan untuk santri,

4) Mengurangi atau membatasi jumlah santri,

5) Memberikan tambahan anggaran untuk pembangunan,

6) Menghindari rangkap jabatan atau tugas pada tiap pengurus agar dapat meningkatkan kinerja,

7) Memberikan tambahan program kegiatan untuk para santri,

8) Ketua yayasan atau pondok pesantren harus menetap di lokasi pondok pesantren.

Melihat penjelasan di atas semakin menegaskan bahwa tingginya tingkat partisipasi orang tua dalam pendidikan sekolah adalah salah satu karakteristik manajemen sekolah yang baik, artinya sejauh mana masyarakat dapat diberdayakan dalam proses pendidikan di sekolah adalah indikator manajemen sekolah yang bersangkutan (Purnomo et al., 2020). Karena itu kemudian pesantren yang baik adalah pesantren yang mampu bertahan hidup di era modern dan berbagai kepungan sekolahsekolah Islam terpadu. Sebab dengan kehadiran sekolah-sekolah Islam terpadu era ini, disinyalir dapat mengancam eksistensi pondok pesantren di Indonesia. Tetapi pernyataan tersebut bisa betul bisa tidak, dengan melihat kehadiran pondok pesantren di Indonesia yang sampai sekarang masih eksis dan terus berkembang, walaupun tetap ada pula yang redup.

\section{Ciri-Ciri Manajemen Pondok Pesantren Modern}

Adanya perubahan dari pondok pesantren di era modern baik dari kultur budaya, peraturan dan nilai yang ditetapkan pondok pesantren. Sekarang ini sistem pondok pesantren tradisonal telah 
banyak yang berubah menjadi sistem modern. Perubahan yang terjadi pada pondok pesantren memerlukan kritik dari masyarakat sekitar sehingga mampu memberikan pelayanan terbaik untuk santri baik dari segi ilmu pendidikan, ilmu keagamaan, ilmu sosial, maupun ekonomi. Contoh dari ciri perubahan dalam memanajemen pondok pesantren modern adalah:

a) Mengubah program pembelajaran dari setiap individu untuk menjadikan sistem klasik yang telah dikenal di kalangan masyarakat menjadi sistem madrasah atau sekolah,

b) Memberikan ilmu pengetahuan secara umum tetapi tetap mengutamakan pengetahuan agama dan bahasa Arab (Putra \& Sholihah, 2020),

c) Adanya tambahan peraturan pendidikan pondok pesantren, contohnya yaitu memiliki kemampuan sesuai dengan keterampilan yang dibutuhkan oleh masyarakat sekitar dan memiliki seni yang Islami,

d) Ketika sudah lulus dari pondok pesantren akan diberikan syahadah atau ijazah untuk tanda sudah selesai di pondok pesantren, dan ada juga yang nilai ijazahnya sama dengan nilai ijazah di sekolah negeri (Daulay, 2014).

Sementara itu, dalam peraturan pondok pesantren yang ada, dalam rangka untuk memberikan penopang dari peraturan pendidikan, maka dibutuhkan strategi mengembangkan salah satu dari pesantren modern yang ada. Dalam kondisi yang berbeda program ini diperlukan untuk sebuah metode atau alat untuk meningkatkan standar peraturan yang ada di pesantren, guna mencapai tujuan yang diinginkan. Terdapat beberapa aspek tentang adanya peraturan pondok pesantren, yaitu: terjadinya masalah terhadap pendidikan dan cara mengajar yang tidak bisa dilakukan oleh ustaz atau kiai sebagai pengajar santri, dan terjadinya konflik antara ustaz atau kiai dengan para murid atau peserta didik yang dapat diselesaikan dengan berunding bersama dengan pihak ketiga (Tolib, 2015).

Menurut Tolib (2015), dalam semua peraturan pendidikan pondok pesantren di era modern, terdapat beberapa bidang yaitu di antaranya sebagai berikut:

1) Bidang pelajaran, bidang pelajaran merupakan bidang yang memiliki kegiatan utama untuk memberikan santri ilmu pengetahuan,

2) Bidang keuangan, bidang keuangan yaitu untuk mengelola dan mengendalikan semua kegiatan yang dilakukan oleh pesantren,

3) Bidang pembinaan, bidang pembinaan ini berfungsi membina santri dan memberikan bantuan terhadap santri dan memberikan semua pelayanan yang dibutuhkan oleh santri.

\section{Strategi dalam Pengembangan Pondok Pesantren}

Dalam pengembangan pondok pesantren di era modern, terdapat beberapa strategi yang dapat digunakan untuk lebih mempertimbangkan berbagai aspek yang akan dilaksanakan. Pengembangan pondok pesantren dapat dilaksanakan dengan berawal dari penerimaan santri baru. Pondok pesantren tradisional dalam penerimaan santri baru masih dilaksanakan dengan cara terbuka yaitu tidak mengadakan semacam tes masuk, artinya seluruh calon santri dapat dengan mudah terdaftar ke dalam pesantren karena dalam penerimaan santri baru tidak memandang latar belakang serta kemampuan calon santri. Selain itu juga jarang dilaksanakan pemetaan atau ketegorisasi santri 
ataupun pengklasifikasian santri berdasarkan kemampuan. Padahal pengkategorian santri sangat penting agar dalam proses pembelajaran serta metode yang digunakan sesuai dengan porsinya serta kebutuhan santri. Selanjutnya dimulai penyiapan fasilitas, sarana prasarana, serta SDM. Selain itu juga mengatur berbagai hal dalam manajemen pesantren dengan baik dan juga mengadakan pelatihan pengajar secara teratur. Untuk menyokong finansial pesantren, pondok pesantren juga harus terus menerus melaksanakan pengelolaan badan usaha semacam koperasi (Mahfud \& Hairit, 2016). Kemudian pondok pesantren juga harus meningkatkan kualitas lulusan dari pondok tersebut. Hal ini agar santri dapat bersaing dengan lulusan dari tingkat sekolah yang lain dan juga dapat memenuhi harapan para petinggi dari pondok pesantren itu sendiri, harapan orang tua, harapan masyarakat, dan negara.

Peningkatan kualitas lulusan ini dapat dilakukan dengan lebih membenahi kurikulum, peningkatan kualitas pengajar, dan peningkatan metode pengajaran serta peningkatan sarana prasarana pondok pesantren. Santoto S Hamijoyo mengemukakan bahwa terdapat beberapa strategi dalam menghadapi permasalahan pendidikan di era modern yaitu lebih mengembangkan bidang ilmu pengetahuan dan teknologi (IPTEK), mengembangkan bidang keterampilan seperti berbahasa asing serta keterampilan manajemen, baik itu pada manajemen personalia, manajemen kelembagaan, maupun manajemen secara keseluruhan yang mencakup pada nilai-nilai kepesantrenan yang sudah sejak lama mengalir. Dengan begitu, mengembangkan pendidikan bagian pengelolaan kependudukan, lingkungan serta keluarga, mengembangkan keagamaan serta ketahanan sosial dan budaya, dan pengembangan kualitas tenaga pengajar serta pelatihan baik pada sistem formal maupun non formal (Saifudin, 2017). Pengembangan pondok pesantren modern sudah memberikan ilmu pengetahuan teknologi untuk mempermudah proses pendidikan formal maupun non-formal.

Pada pondok pesantren modern, selain terdapat pengurus seperti kiai, pengajaran kitab-kitab klasik, masjid yang memadai, juga diperlukan faktor pendukung untuk menambah dinamika di pondok pesantren. Di antaranya adalah adanya transparansi pada sistem kepengasuhan, penyediaan sarana dan prasarana yang memadai dengan memanfaatkan perkembangan teknologi modern, dan sebagainya. Hal tersebut dapat terwujud dengan adanya dukungan dari semua pihak termasuk pengasuh, santri, wali santri, serta seluruh elemen masyarakat yang ada di sekitar pondok.

Menyikapi perkembangan pada era modern ini, tokoh pesantren KH. Sahal Mahfudz berpendapat bahwa: Jika pesantren menginginkan berhasil dalam melaksanakan pengembangan masyarakat, maka pesantren harus melengkapi dirinya dengan tenaga yang terampil, mengelola sumber daya yang ada di lingkungannya, di samping syarat lainnya, pesantren harus tetap menjaga potensinya sebagai lembaga pendidikan Islam (Hartono, 2012). Hal ini memberikan pesan yang artinya bahwa pondok pesantren harus berubah dan mengikuti perkembangan zaman dan tidak boleh termatikan karena perkembangan zaman yang makin keras, pondok pesantren sebagai tempat belajar agama harus memiliki keberanian untuk tetap eksis menjadi lembaga pendidikan Islam. Manajemen juga sangat penting agar pondok pesantren itu sendiri dapat berpartisipasi dalam kehidupan di dunia pada era modern saat ini.

\section{Kesimpulan}

Pondok pesantren modern merupakan pengembangan pondok pesantren tradisional. Pondok pesantren diharapkan dapat selalu menyesuaikan atau berubah dan mengikuti perkembangan zaman 
agar tidak tertinggal karena perkembangan zaman yang semakin canggih. Pondok pesantren sebagai tempat belajar ilmu agama dan keislaman harus memiliki keberanian untuk tetap eksis menjadi lembaga pendidikan Islam walaupun menghadapi tantangan berat dalam dunia digital. Pondok pesantren di era modern, memiliki beberapa bidang yang perlu diperhatikan, utamanya pada bidang pelajaran, bidang keuangan, dan bidang pembinaan. Bidang pelajaran memiliki kegiatan utama untuk memberikan santri ilmu pengetahuan. Bidang keuangan untuk mengelola dan mengendalikan semua kegiatan yang dilakukan oleh pesantren. Terakhir bidang pembinaan berfungsi membina santri dan memberikan bantuan terhadap santri dan memberikan semua pelayanan yang dibutuhkan. Di era modern seperti sekarang ini, pondok pesantren harus lebih pintar dalam mengelola pondok itu sendiri, baik dalam pengelolaan keuangan, input, dan output santri, sarana dan prasarana, serta pengembangan kurikulum pondok pesantren.

\section{Referensi}

Azra, A. (2019). Pendidikan Islam: Tradisi dan Modernisasi di Tengah Tantangan Milenium III. Prenada Media.

Daulay, H. H. P. (2014). Pendidikan Islam dalam Sistem Pendidikan Nasional di Indonesia. Kencana.

Halim, A., \& Mas'ud, A. R. (2005). Manajemen Pesantren Dalam Menghadapi Dunia Global. Tarbawi, 1(02), 97-106. https://books.google.com/books?id=NElcVVZ1dBYC\&pgis=1

Hartono, D. (2012). Pengembangan Manajemen Pondok Pesantren di Era Globalisasi: Menyiapkan Pondok Pesantren Go Internasional. Ponpes Jagad 'Alimussirry.

Hasan, M. (2016). Inovasi Dan Modernisasi Pendidikan Pondok Pesantren. KARSA: Jurnal Sosial Dan Budaya Keislaman, 23(2), 296. https://doi.org/10.19105/karsa.v23i2.728

Hayati, N. (2015). MANAJEMEN PESANTREN DALAM MENGHADAPI DUNIA GLOBAL. Tarbawi: Jurnal Keilmuan Manajemen Pendidikan, 1(02), 97-106. doi:10.32678/tarbawi.v1i02.2006

Hidayat, A., \& Machali, I. (2012). Pengelolaan Pendidikan: Konsep, Prinsip, dan Aplikasi dalam Mengelola Sekolah dan Madrasah. Kaukaba.

Mahfud, M., \& Hairit, A. (2016). Pondok Pesantren Masa Depan (Studi Pola Manajemen PP. Nahdlatun Nasyiin Bungbaruh Kadur Pamekasan). Fikrotuna, 4(2). https://doi.org/10.32806/jf.v4i2.2750

Madjid, N. (1997). Bilik-bilik Pesantren: Sebuah Potret Perjalanan. Paramadina.

Muhs, W. F. (1982). Worker participation in the progressive Era: An assessment by harrington emerson. Academy of Management Review, 7(1), 99-102. https://doi.org/10.5465/amr.1982.4285481

Muzakki, H., \& Nisa', K. M. (2020). Basis Transformasi Tradisi Pesantren Salaf di Era Modern (Kajian Semiotika Barthes dan Dekonstruksi Derrida). QALAMUNA: Jurnal Pendidikan, Sosial, Dan Agama, 12(01), 91-105. https://doi.org/10.37680/qalamuna.v12i01.304

Nata, H. A. (2012). Manajemen Pendidikan: Mengatasi Kelemahan Pendidikan Islam di Indonesia. Kencana.

Purnomo, H., Mansir, F., \& Tumin, T. (2020). School Relationship Management with the Community: Analysis of Program Activity Needs. AL-ASASIYYA: Journal Of Basic 
Education, 4(2), 161-172. https://doi.org/10.24269/ajbe.v4i2.2623

Putra, W. H., \& Sholihah, R. A. (2020). Politik Bahasa Asing dan Hegemoni Pesantren di Nusantara. Aphorisme: Journal of Arabic Language, Literature, and Education, 1(1), 43-53. https://doi.org/10.37680/aphorisme.v1i1.320

Rohmatulloh, D. (2018). Peta Dinamika Dakwah dalam Mobilitas Muslim Indonesia di Abad ke-20. MUHARRIK: Jurnal Dakwah Dan Sosial, $\quad$ 1(01), 86-96. https://doi.org/10.5281/zenodo.3545043

Romlah. (2016). Manajemen Pendidikan Islam. Harakindo Publishing.

Saifudin, A. (2017). Manajemen Pesantren dalam Menghadapi Perubahan. Intizam, Jurnal Manajemen Pendidikan Islam, 1(1), 61-77.

Sugiarti, D. Y. (2011). Strategi Pengembangan Pondok Pesantren Dalam Membangun Peradaban Muslim di Indonesia. Edukasi, 3(1), 8-37.

Suryana, E. (2017). Manajemen Kelas Berkarakteristik Siswa. Edukasi Islami: Jurnal Pendidikan Islam, 1(02).

Syafa'at, A. K., Aimah, S., Ekaningsih, L. A. F., \& Mahbub, M. (2014). Strategi Pengembangan Pondok Pesantren dalam Era Globalisasi di Kabupaten Banyuwangi. INFERENSI: Jurnal Penelitian Sosial Keagamaan, 8(1), 245-269. https://doi.org/10.18326/infs13.v8i1.245-269

Tolib, A. (2015). Pendidikan di Pondok Pesantren Modern. Risâlah, Jurnal Pendidikan Dan Studi Islam, 2(1), 60-66.

Yahya, U. (2016). Konsep Pendidikan Anak Usia Sekolah Dasar (6-12) Tahun Di Lingkungan Keluarga Menurut Pendidikan Islam. Islamika: Jurnal Ilmu-Ilmu Keislaman, 15(2). 